\title{
Detection of Canine Herpesvirus DNA in the Ganglionic Neurons and the Lymph Node Lymphocytes of Latently Infected Dogs
}

\author{
Masahiro MIYOSHI, Yuki ISHII, Mitsuyoshi TAKIGUCHI, Ayato TAKADA²), Jun YASUDA ${ }^{1)}$, Akira HASHIMOTO*, \\ Katsunori OKAZAKI ${ }^{2)}$ and Hiroshi KIDA ${ }^{2)}$ \\ Department of Veterinary Clinical Sciences, Graduate School of Veterinary Medicine, ${ }^{l)}$ Veterinary Teaching Hospital, Faculty of \\ Veterinary Medicine, and ${ }^{2}$ Department of Disease Control, Graduate School of Veterinary Medicine, Hokkaido University, Sapporo \\ 060-0818, Japan
}

(Received 18 November 1998/Accepted 7 December 1998)

ABSTRACT. To determine the site of latent infection of canine herpesvirus (CHV), tissues from dogs convalescent from acute infection with CHV were examined for the presence of viral genome DNA by the nested polymerase chain reaction. CHV DNA was detected in the trigeminal ganglia and the retropharyngeal lymph nodes. In situ hybridization study of the tissues revealed that CHV genome persisted in the nuclei of ganglionic neurons and lymphocytes.-KEY wORDs: canine herpesvirus, ganglionic neuron, latency, lymphocyte.

Canine herpesvirus (CHV) causes a generalized necrotizing and hemorrhagic disease in neonatal pups, and usually subclinical upper respiratory infection in adult dogs [1]. It has been indicated that $\mathrm{CHV}$ persists in the trigeminal ganglion or a variety of tissues of naturally infected dogs as viral DNA, and that stress or administration of corticosteroid leads reactivation of the virus $[4,14]$. CHV belongs to the alphaherpesvirus group, containing feline herpesvirus 1 (FHV-1), equine herpesvirus 1 (EHV-1), bovine herpesvirus 1 (BHV-1) and pseudorabies virus (PRV) [18]. Recent studies demonstrated that the genomes of alphaherpesviruses harbored in the ganglionic neurons [2, 13, 17, 19] as well as in lymphocytes during latent infection [5].

To determine cell types where CHV latently infects, tissues of dogs convalescent from experimental infection with the virus via different routes were examined for the viral DNA by using nested polymerase chain reaction (PCR) and in situ hybridization.

\section{MATERIALS AND METHODS}

Virus, cells and animals: The GCH-1 strain of CHV was used for all inoculations. The origin and history of the strain were presented in previous report [8]. The strain was passaged 40 times and propagated in Madine-Darby canine kidney (MDCK) cells. The cells were grown in modified Eagle's minimal essential medium (MEM) supplemented with $5 \%$ calf serum, penicillin $(100 \mathrm{U} / \mathrm{m} l)$, streptomycin $(100 \mu \mathrm{g} / \mathrm{ml})$ and nonessential amino acids. Nine adult $(>2$ years) dogs of female weighing $10.8-14.7 \mathrm{~kg}$ were used in this study. Nos. 1 and 2 were mongrels, others were beagles. They were all seronegative to $\mathrm{CHV}$ at the time of inoculations. The viruses of $2 \times 10^{6} \mathrm{TCID}_{50}$ were inoculated intranasally to two dogs (Nos. 1 and 2). The same doses of the virus were inoculated both intravenously and intranasally to three animals (Nos. 3, 4 and 5). The same doses of the virus were inoculated intravaginally to three animals (Nos.

\section{6, 7 and 8).}

Virus isolation and titration: Nasal and vaginal swabs were taken every 2 nd day for 2 weeks after inoculation with CHV. Thereafter, the swabs were collected every other week until dogs were dissected. All swabs were placed in chilled MEM and kept in $-80^{\circ} \mathrm{C}$ until use. After thawing the samples, serial 10-fold dilutions were prepared in MEM and $50 \mu l$ amount of each dilution was inoculated onto monolayers of MDCK cells in 96-well tissue culture plates.

Collection of materials: Two or four months after inoculation, the animals were sacrificed and tissues listed in Table 2 were collected. Peripheral blood mononuclear cells (PBMCs) were collected from $2 \mathrm{~m} l$ of blood by using Ficoll-Paque reagent (Pharmacia Biotech). These collected samples were kept at $-40^{\circ} \mathrm{C}$ or fixed with paraformaldehyde for immunological staining and for in situ hybridization.

DNA extraction from the tissues and nested PCR: Genomic DNA was extracted from tissue homogenates (10 $\mathrm{mg}$ ) digested by proteinase $\mathrm{K}$, using phenol and chloroform [20]. CHV immediate early (IE) gene within the inverted repeats was amplified by nested PCR using the genomic DNA (Fig. 1) [3]. The first PCR was performed in a $25 \mu l$ volume containing $0.25 \mu l$ of DNA, $20 \mathrm{mM}$ Tris- $\mathrm{HCl}$ (pH8.4), $50 \mathrm{mM} \mathrm{KCl}, 1.5 \mathrm{mM} \mathrm{MgCl}_{2}, 200 \mu \mathrm{M} \mathrm{dNTP}$ mixture, 1.25U Taq DNA polymerase (GIBCO BRL), 50 $\mu \mathrm{M}$ IE-1 primer (5'-GATAATTCAGCTTCTAGCGATG $3^{\prime}$ ) and $50 \mu \mathrm{M}$ IE-2 primer (5'-GATCTCACATC TATAGTTTGGAG-3'). After denaturation at $94^{\circ} \mathrm{C}$ for 1 min, amplification was carried out for 30 cycles: $45 \mathrm{sec}$ of denaturation at $93^{\circ} \mathrm{C}, 30 \mathrm{sec}$ of annealing at $56^{\circ} \mathrm{C}$, and 1 min of extension at $71^{\circ} \mathrm{C}$. The final cycle was terminated with a 3 min extension at $71^{\circ} \mathrm{C}$. The PCR products were diluted in distilled water to give $1 / 10$ concentrations. The nested PCR was performed in a $25 \mu l$ volume containing 1 $\mu l$ diluted PCR products, $50 \mu \mathrm{M}$ IE-1N primer (5'AACCAACTCCAGCTAAAGCAT-3'), $50 \mu \mathrm{M}$ IE-2N 


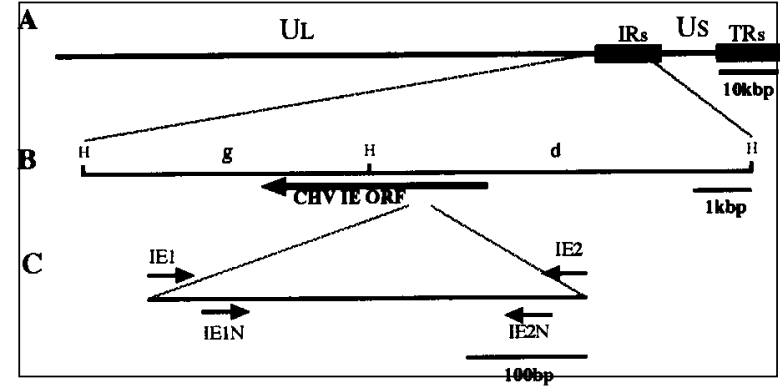

Fig. 1. Schema of the CHV genome and the target of nested PCR. (A) Schema of the CHV genome. UL:unique long region. IRs:internal repeats. US:unique short region. TRs:terminal repeats. (B) The Hind III d and g fragments. The CHV IE ORF is shown by arrow. (C) The summary of primers used in nested PCR. Direction are shown by arrows. The length of the DNA fragment producted by nested PCR is 355 bps.

primer (5'-GTTGATTCATTAGGTAAAGCATT-3') as above. The primer pairs of IE-1/IE-2 and IE-1N/IE-2N were synthesized according to the sequences reported previously [10].

Virus isolation from the tissue homogenates: Nerve ganglia and lymph nodes were homogenized in MEM to give concentrations of $10 \%$, then inoculated to MDCK cells and 3 passages were made at weekly intervals.

Immunohistochemical staining: The streptavidin biotin complex (SAB) method was applied to the trigeminal ganglia and retropharyngeal lymph node sections to detect viral antigens. Rabbit immune serum against $\mathrm{CHV}$ virions was used as primary antibodies. For antibody detection the Histofine SAB-Kit was used according to the manufacturer's instruction (Nichirei)

In situ hybridization: Tissues were fixed in $4 \%$ paraformaldehyde for 3 or 4 days at $4{ }^{\circ} \mathrm{C}$ and embedded in paraffin for sectioning. The tissue sections on glass slides were washed in xylene for $20 \mathrm{~min}$ to remove paraffin. The sections were dehydrated in graded ethanol solutions and washed twice in $0.1 \mathrm{M}$ phosphate buffer $(\mathrm{pH} 7.4, \mathrm{~PB})$ for $15 \mathrm{sec}$, treated with proteinase $\mathrm{K}(1-200 \mu \mathrm{g} / \mathrm{ml})$ for $15 \mathrm{~min}$ at $37^{\circ} \mathrm{C}$, and fixed in $4 \%$ paraformaldehyde for $10 \mathrm{~min}$. As a control, the proteinase $\mathrm{K}$-digested sections were treated with RNase-free DNase $(200 \mu \mathrm{g} / \mathrm{ml})$ for $1 \mathrm{hr}$ at $37^{\circ} \mathrm{C}$. Then the sections were washed in $\mathrm{PB}$ for $1 \mathrm{~min}$ and treated with $0.2 \mathrm{~N} \mathrm{HCl}$ for $10 \mathrm{~min}$, washed in $\mathrm{PB}$ for $1 \mathrm{~min}$, dipped in $0.1 \mathrm{M}$ triethanolamine- $0.25 \%$ (vol./vol.) acetic anhydride for $10 \mathrm{~min}$, washed in PB for $1 \mathrm{~min}$, and dehydrated in $80 \%$ and $100 \%$ ethanol for $3 \mathrm{~min}$. The slides were dried completely on hot plate at $50^{\circ} \mathrm{C}$ for $2 \mathrm{hr}$. Sections were hybridized with $25 \mathrm{ng}$ of the CHV IE DNA probe labeled with Digoxigenin (DIG)-TTP by PCR using primers IE-1N and IE- $2 \mathrm{~N}$, per slide for $16 \mathrm{hr}$ at $42^{\circ} \mathrm{C}$ in $2 \times \mathrm{SSC}(1 \times \mathrm{SSC}$ is $0.15 \mathrm{M} \mathrm{NaCl}$ plus $0.015 \mathrm{M}$ sodium citrate) containing $45 \%$ formamide, $10 \%$ dextran sulphate, $10 \mathrm{mM}$ Tris- $\mathrm{HCl}$ $(\mathrm{pH} 7.4), 1 \mathrm{mM}$ EDTA, $1 \times$ Denhart's solution $(0.02 \%$ bovine serum albumin, $0.02 \%$ polyvinylpyrolidone, $0.02 \%$
Ficoll) and $1.0 \mathrm{mg} / \mathrm{m} l \mathrm{tRNA}$ of brewer's yeast. Following hybridization, slides were washed in $5 \times \mathrm{SSC}$ for $1 \mathrm{~min}, 2 \times$ SSC and $50 \%$ formamide for $30 \mathrm{~min}$, and washed twice in $0.2 \times \mathrm{SSC}$ for $20 \mathrm{~min}$ each at $42^{\circ} \mathrm{C}$. Detection of hybrids with anti-DIG alkaline phosphatase-conjugate were performed by use of X-phosphate and nitro blue tetrazolium according to the manufacture's instructions (Boehringer Mannheim).

\section{RESULTS}

Virus recovery from the dogs inoculated with $\mathrm{CHV}$ via different routes: $\mathrm{CHV}$ was isolated only from the nasal swabs of dogs inoculated intranasally or both intranasally and intravenously until four or six days after inoculation. On the other hand, CHV was isolated from both nasal and vaginal swabs of dogs inoculated intravaginally until four or six days after inoculation (Table 1). No dog showed clinical signs. Serum neutralization antibody titers of all animals increased until three or four weeks after inoculation, then decreased (data not shown).

Detection of CHV genome DNA in the tissues of convalescent dogs by nested PCR: The results of nested PCR of DNA templates extracted from various tissues of nine dogs are shown in Table 2. All animals harbored CHV genome in the trigeminal ganglia, irrespective of inoculation routes. The viral DNA was detected in the retropharyngeal lymph nodes of 7 of 8 dogs. CHV genome DNA was also detected in the lumbosacral ganglions (Nos.2, 3, 6 and 7), tonsils (Nos.2 and 3), mediastinal lymph nodes (No. 3), thymus (No. 3) and hypogasteric lymph nodes (Nos. 6, 7 and 8). The CHV DNA was not detected in the PBMCs by nested PCR. The amplified fragment was confirmed as a portion of CHV genome by Southern blot hybridization (data not shown). The sensitivity of nested PCR/Southern blot analysis were equivalent to $1 \mathrm{TCID}_{50}$. No virus was recovered from the tissue homogenates and no antigen was detected on these tissue sections by immunohistochemical staining using rabbit hyper-immune serum against $\mathrm{CHV}$ virions. Treatment of the convalesent animals with dexamethasone increased serum neutralization antibody titers, although no virus was recovered (data not shown). These findings indicate latent infection in the animals by CHV.

In situ hybridization of $C H V$ genome in the trigeminal ganglia and the retropharyngeal lymph nodes: In order to identify the cell types where CHV genome harbored during the phase of latent infection, in situ hybridization was performed on sections of the trigeminal ganglia and the retropharyngeal lymph nodes of animals latently infected with CHV. Of the 6 ganglia tested, 4 (Nos.1, 4, 6 and 7) were positive for $\mathrm{CHV}$ genome. Signals were found only in the nuclei of the neurons (Fig. 2). Positive rate of neurons latently infected with the virus were between $0.01 \%$ to $0.04 \%$. No signal was observed in the control sections treated with DNase and in the sections hybridized with DIGlabeled probe solution containing excess amount of 
Table 1. Isolation of CHV from swabs after inoculation

\begin{tabular}{|c|c|c|c|c|c|c|c|}
\hline \multirow{2}{*}{$\begin{array}{c}\text { Animal } \\
\text { No. }\end{array}$} & \multirow{2}{*}{$\begin{array}{l}\text { Swabbed } \\
\text { sites }\end{array}$} & \multicolumn{6}{|c|}{ Days after inoculation } \\
\hline & & 2 & 4 & 6 & $8-14^{\text {b) }}$ & $28-56$ & $70-112$ \\
\hline \multicolumn{8}{|c|}{ Intranasal inoculation } \\
\hline \multirow[t]{2}{*}{1} & Nose & $4.0^{\mathrm{a})}$ & 3.5 & - & - & - & \\
\hline & Vagina & - & - & - & - & - & \\
\hline \multirow[t]{2}{*}{2} & Nose & 3.67 & 4.0 & 1.0 & - & - & - \\
\hline & Vagina & - & - & - & - & - & - \\
\hline \multicolumn{8}{|c|}{ Intranasal and intravenous inoculation } \\
\hline \multirow[t]{2}{*}{3} & Nose & 4.33 & 3.5 & 0.67 & - & - & - \\
\hline & Vagina & - & - & - & - & - & - \\
\hline \multirow[t]{2}{*}{4} & Nose & 4.0 & 3.33 & 0.5 & - & - & - \\
\hline & Vagina & - & - & - & - & - & - \\
\hline \multirow[t]{2}{*}{5} & Nose & 4.33 & 2.0 & - & - & - & - \\
\hline & Vagina & - & - & - & - & - & - \\
\hline \multicolumn{8}{|c|}{ Intravaginal inoculation } \\
\hline \multirow{2}{*}{6} & Nose & - & 1.0 & - & - & - & \\
\hline & Vagina & 2.5 & 2.0 & - & - & - & \\
\hline \multirow[t]{2}{*}{7} & Nose & - & 0.83 & - & - & - & \\
\hline & Vagina & 1.0 & 2.33 & 1.5 & - & - & \\
\hline \multirow[b]{3}{*}{ Control (not } & Nose & - & 3.67 & 0.67 & - & - & \\
\hline & Vagina & 2.0 & 3.5 & - & - & - & \\
\hline & \multicolumn{7}{|c|}{ Control (not inoculated) } \\
\hline \multirow[t]{2}{*}{9} & Nose & - & - & - & - & - & - \\
\hline & Vagina & - & - & - & - & - & - \\
\hline
\end{tabular}

a) Virus titers are expressed as $\log _{10} \mathrm{TCID}_{50} 50 \mu l$.

-: No virus was isolated.

b) 8-14: Samples were collected every 2 nd days.

28-56: Samples were collected two weeks apart.

56-112: Samples were collected two weeks apart.

Table 2. Detection of CHV genome in the tissues of latently infected dogs

\begin{tabular}{lccccccccc}
\hline & \multicolumn{1}{c}{ Animal No. } \\
\cline { 2 - 8 } Tissue & $1^{\text {a) }}$ & 2 & 3 & 4 & 5 & 6 & 7 & 8 & 9 \\
\hline Cerebrum & & & & & & & & & \\
Cerebellum & - & - & - & - & - & - & - & - & - \\
Cornea & - & - & - & - & - & - & - & - & - \\
Lacrimal gland & - & - & - & - & - & - & - & - & - \\
Nasal swab & - & - & - & - & - & - & - & - & - \\
Parotid gland & - & - & - & - & - & - & - & - & - \\
Trigeminal ganglion & + & + & + & + & + & + & + & + & - \\
Tonsil & - & + & + & - & - & - & - & - & - \\
Retropharingeal lymph node & + & + & + & + & + & - & + & + & - \\
Axillares lymph node & $\mathrm{nc}$ & - & - & - & - & - & - & - & - \\
Thymus & - & - & + & - & - & - & - & - & - \\
Lung & - & - & - & - & - & - & - & - & - \\
Pulmonales lymph node & - & - & + & - & - & - & - & - & - \\
Liver & - & - & - & - & - & - & - & - & - \\
Spleen & - & - & - & - & - & - & - & - & - \\
Kidney & - & - & - & - & - & - & - & - & - \\
Lumbosacral ganglion & - & + & + & - & - & + & + & - & - \\
Hypogasteric lymph node & - & - & - & - & - & + & + & + & - \\
Mammary lymph node & $\mathrm{nc}$ & - & - & - & - & - & - & - & - \\
Endometrium & - & - & - & - & - & - & - & - & - \\
Vaginal swab & - & - & - & - & - & - & - & - & - \\
PBMCs & - & - & - & - & - & $\mathrm{nc}$ & $\mathrm{nc}$ & $\mathrm{nc}$ & - \\
\hline
\end{tabular}

a) Nos.1 and 2 :intranasal inoculation. Nos.3, 4 and 5 :intranasal and intravenous inoculation. Nos. 6, 7 and 8 :intravaginal inoculation. No.9 :control (not inoculated).

b) +: Positive. -: Negative. nc: not collected. 


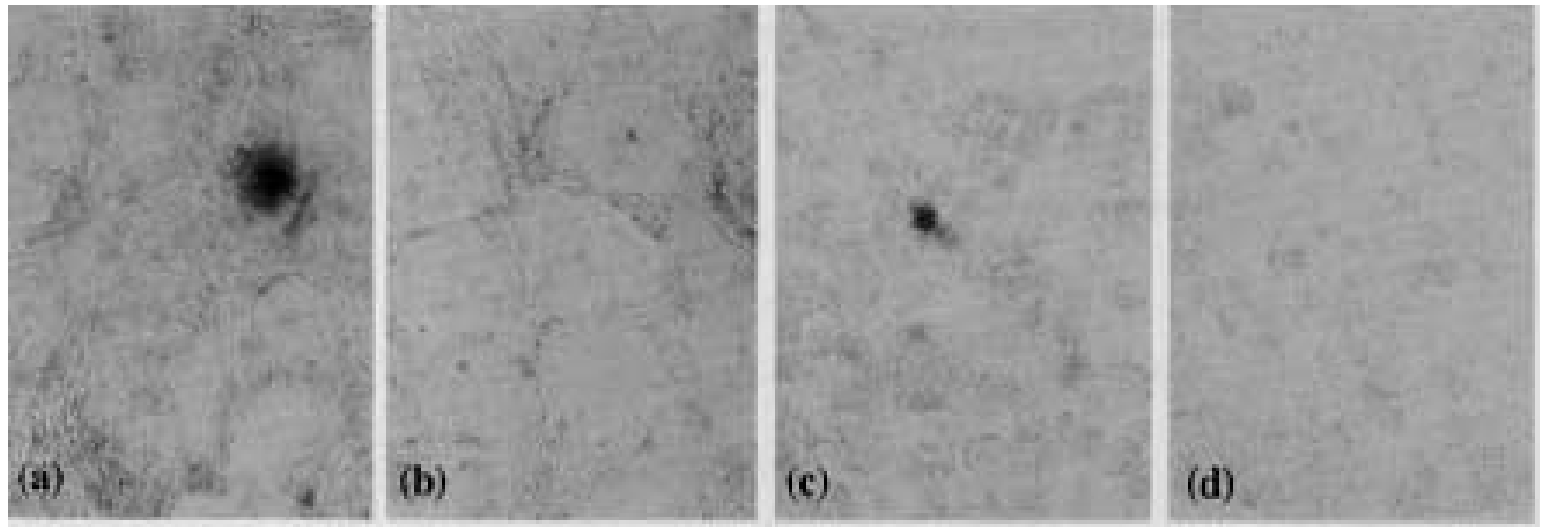

Fig. 2. In situ hybridization on the trigeminal ganglia and retropharingeal lymph nodes from latently infected dogs. Positive signal was detected in the nucleus of a neuron in the trigeminal ganglion (a) and the nucleus of a lymphocyte in the retropharingeal lymph node $(c)(\times 200)$. DNase-treated section of the trigeminal ganglion $(b)$ and retropharyngeal lymph node (d) $(\times 200)$.

unlabeled CHV DNA. In the retropharyngeal lymph nodes, CHV genomes were detected in the nuclei of lymphocytes from 3 animals (Nos. 2, 4 and 8) (Fig. 2). Frequency of positive lymphocytes ranged from $1 \times 10^{-9}$ to $5 \times 10^{-7}$.

\section{DISCUSSION}

In the present study, $\mathrm{CHV}$ genome was detected in the trigeminal ganglia of dogs experimentally infected with $\mathrm{CHV}$, while infectious virus was not recovered from the tissue homogenates. These findings indicate that $\mathrm{CHV}$ genome remained latent in the animals. During the acute phase, all $\operatorname{dogs}$ shed the virus in the nasal secretions irrespective of routes of inoculations, showing that $\mathrm{CHV}$ replicated in their nasal mucosa. Although it was uncertain whether the animals were "reinfected" with the virus shed in the vaginal secretions or systemic infection occurred, the virus must be transported to the trigeminal ganglia from sensory nerve endings $[6,16]$. In situ hybridization study demonstrated that $\mathrm{CHV}$ genome harbored in the nuclei of neurons in the trigeminal ganglia. The trigeminal ganglia of animals have been identified as the site of latent infection of FHV-1, EHV-1, BHV-1 and PRV [2, 7, 13, 17].

$\mathrm{CHV}$ genome was also detected in the lumbosacral ganglia of two animals inoculated with the virus intranasally or both intranasally and intravenously in the present study. Although no virus was recovered from vaginal swabs of these animals, CHV must replicate in the epithelial cells of vagina and be transported to the ganglia. It was suggested that the lumbosacral ganglion was an important site for latency and that recrudescent virus played an important role in venereal infections [4]. Since CHV infection in pregnant dogs causes abortion and stillbirth, the mechanism of reactivation of $\mathrm{CHV}$ should be clarified $[9,15]$.

$\mathrm{CHV}$ genome was also detected in the retropharyngeal lymph nodes of all but one animal, and detected in the hypogasteric lymph nodes of those inoculated intravaginally. These results suggest that the lymphocytes were infected with the virus that replicated in epithelial cells of mucosa and migrated to these lymph nodes. In the animals intravenously inoculated with $\mathrm{CHV}$, viral genome was detected in a variety of lymphoid tissues. This finding suggests that $\mathrm{CHV}$ genome circulate systemically via blood or lymphatic fluid as shown with other herpesviruses $[5,11$, 12]. In the present study, CHV genomic DNA was not detected in PBMCs. To make clear whether the infected lymphocytes circulate systemically, further investigations are necessary. It was reported that PRV-infected blood mononuclear cells caused abortion by transmitting the virus to placental cells [12].

Latent infection of herpesviruses is implicated in a variety of diseases following reactivation [21]. The present results provided information of CHV latency, and the usefulness of PCR and in situ hybridization techniques for the diagnosis of latent CHV infection.

ACKNOWLEDGMENTS. The authors are grateful to Drs. R. Mukaiya and T. Kimura of Hokkaido University for support of pathological techniques.

\section{REFERENCES}

1. Appel, M. J. G. 1987. Canine herpesvirus. pp. 5-14. In: Virus infections of carnivores (Appel, M. J. G. ed), Elsevier Science Publication, Amsterdam.

2. Baxi, M. K., Efstathiou, S., Lawrence, G., Whalley, J. M., Alater, J. D. and Field, H. J. 1995. The detection of latencyassociated transcripts of equine herpesvirus 1 in ganglionic neurons. J. Gen. Virol. 76: 3113-3118.

3. Belak, S. and Ballagi-Pordany, A. 1993. Application of the polymerase chain reaction (PCR) in veterinary diagnostic virology. Vet. Res. Commun. 17: 55-72.

4. Burr, P. D., Campbell, M. E. M., Nicolson, L. and Onions, D. E. 1996. Detection of canine herpesvirus 1 in a wide range of tissues using the polymerase chain reaction. Vet. Microbiol. 53: 227-237.

5. Chesters, P. M., Allsop, R., Purewai, A. and Edington, N. 
1997. Detection of latency-associated transcripts of equid herpesvirus 1 in equine leukocytes but not in trigeminal ganglia. J. Virol. 71: 3437-3443.

6. Cook, M. L. and Stevens, J. G. 1973. Pathogenesis of herpetic neuritis and ganglionitis in mice: Evidence for intra-axonal transport of infection. Infect. Immun. 7: 272288.

7. Gutekunst, D. E. 1979. Latent pseudorabies virus infection in swine detected by RNA-DNA hybridization. Am. J. Vet. Res. 40: $1568-1572$.

8. Hashimoto, A., Hirai, K., Miyoshi, A., Shimakura, S., Yagami, K., Kato, N., Kunihiro, K., Fujiura, A., Okuda, K. and Fujimoto, Y. 1978. Naturally occurring canine herpesvirus infection in Japan. Jpn. J. Vet. Sci. 40: 157-169.

9. Hashimoto, A., Hirai, K., Yamaguchi, T. and Fujimoto, Y. 1982. Experimental transplacental infection of pregnant dogs with canine herpesvirus. Am. J. Vet. Res. 43: 844-850.

10. Miyoshi, M., Takiguchi, M., Yasuda, J., Hashimoto, A., Takada, A., Okazaki, K. and Kida, H. 1999. Structure of the immediate early gene of canine herpesvirus. Arch. Virol. 144: 407-420.

11. Mweene, A. S., Okazaki, K. and Kida, H. 1996. Detection of viral genome in non-neural tissues of cattle experimentally infected with bovine herpesvirus 1. Jpn. J. Vet. Res. 44: 165174.

12. Nauwynck, H. J. and Pensaert, M. B. 1992. Abortion induced by cell-associated pseudorabies virus in vaccinated sows. Am. J. Vet. Res. 53: 489-493.

13. Ohmura, Y., Ono, E., Matsuura, T., Kida, H. and Shimizu, Y. 1993. Detection of feline herpesvirus 1 transcripts in trigemi- nal ganglia of latently infected cats. Arch. Virol. 129: 341347.

14. Okuda, Y., Ishida, K., Hashimoto, A., Yamaguchi, T., Fukushi, H., Hirai, K. and Carmichael, L. E. 1993. Virus reactivation in bitches with a medical history of herpesvirus infection. Am. J. Vet. Res. 54: 551-554.

15. Poste, G. and King, N. 1971. Isolation of herpesvirus from the canine genital tract: Association with infertility, abortion and stillbirth. Vet. Rec. 88: 229-233.

16. Puga, A., Rosenthal, L. D., Openshaw, H. and Notkins, A. L. 1978. Herpes simplex DNA and mRNA sequences in acutely and chronically infected trigeminal ganglia of mice. Virology 61: 1700-1703.

17. Rock, D. L., Hagemoser, W. A., Osorio, F. A. and Reed, D. E. 1986. Detection of bovine herpesvirus type 1 RNA in trigeminal ganglia of latently infected rabbits by in situ hybridization. J. Gen. Virol. 67: 2515-2520.

18. Roizman, B., Desrosiers, R. C., Fleckenstein, B., Lopez, C., Minson, A. C. and Studdert, M. J. 1992. The family Herpesviridae: and update. Arch. Virol. 123: 425-449.

19. Rziha, H. J., Mettenleiter, T. C., Ohlinger, V. and Wittmann, V. 1986. Herpesvirus (pseudorabies virus) latency in swine: occurrence and physical state of viral DNA in neural tissue. Virology 155: 600-613.

20. Sambrook, J., Fritsch, E. F. and Maniatis, T. 1989. Molecular cloning : A laboratory manual, 2nd ed., Cold Spring Harbor Laboratory Press, New York.

21. Whitley, R. J. 1990. Herpes simplex viruses. pp. 1843-1887. In: Virology (Fields, B. N. and Knipe, D. M. eds.), Raven Press Limited, New York. 